\title{
Factors Affecting English Language Teaching and Learning in Higher Education
}

\author{
Hong Thi Nguyen ${ }^{1}$, Wendy Warren ${ }^{1} \&$ Heather Fehring ${ }^{1}$ \\ ${ }^{1}$ School of Education, RMIT University, Melbourne, Australia \\ Correspondence: Hong Thi Nguyen, School of Education, RMIT University, Melbourne, Australia. Email: \\ nguyenhong2510@yahoo.com.vn
}

$\begin{array}{ll}\text { Received: May 26, } 2014 & \text { Accepted: June 27, } 2014 \quad \text { Online Published: July 15, } 2014 \\ \text { doi:10.5539/elt.v7n8p94 } & \text { URL: http://dx.doi.org/10.5539/elt.v7n8p94 }\end{array}$

\begin{abstract}
This paper reports part of a study that aims to explore factors affecting the efficacy of non-major English teaching and learning in Vietnamese higher education through an investigation of classroom practices. Eight non-participant class observations were conducted at HUTECH University, Ho Chi Minh City, Vietnam. The study's findings show that many factors hinder the quality of English teaching and learning: uninteresting teaching style; insufficient time for communicative activities; grammar-driven teaching; unreasonable time-management; unclear instructions; large class sizes; teachers' limited ability in classroom organization; unequal students' English levels; inadequate lesson preparation; teachers' limited use of teaching aids and technology; and students' lack of confidence in using oral English in class activities. Based on these results, recommendations are given to improve the quality of non-major English teaching and learning, at HUTECH University in particular and in Vietnamese higher education in general.
\end{abstract}

Keywords: non-major English, classroom practices, higher education, English teaching, English learning, Vietnamese

\section{Introduction}

No matter if it is difficult or easy to master a language, it is a prolonged and consistent period. Acquiring or learning a language requires much time and effort from not only the learners, but from the teachers as well. Nowadays, when English is considered as an international language, the activity of teaching and learning English as a foreign or second language is also examined and discussed widely all over the world. This paper will contribute to this discussion, by adding a voice from Vietnam.

\section{Language Teaching and Learning}

In discussion about language teaching and learning, Brown (2007a) points out that, there is a depending and subordinating relationship between teaching and learning. Teaching plays roles as guiding, facilitating learning, and encouraging the learner and setting the conditions for learning. Having a good understanding of how the learner learns will help teachers determine their philosophy of education, their teaching style, approach, methods, and classroom techniques. According to Cook (2001), "the proof of teaching is in the learning", and "all successful teaching depends upon learning" (p. 9). Cook also states that there is no point in providing interesting, well prepared language lessons if students do not learn from them.

\subsection{Goal of Language Teaching and Learning}

It is important for teachers and learners to understand the goal of language teaching and learning, as well as how to achieve it. It is pointed out that the goal of language teaching is to develop learners' communicative competence. (Liu, 2003; Rivers, 1978). As advised in Rivers (1978), "when selecting learning activities, we must always remember that our goal is for the students to be able to interact freely with others: to understand what others wish to communicate in the broadest sense, and to be able to convey to others what they themselves wish to share" (Rivers, 1978, pp. 3-4). Following this point, Liu (2003) believes that the ultimate goal of language instruction is to equip learners with the ability to use the language for their communication. This reasonably explains why the four macro language skills (listening, speaking, reading, writing) fall into the two categories: vocal and written communication. Listening and speaking are the most important forms of vocal communication, whereas reading and writing are the most important forms of written communication. 


\subsection{Major Methods in Language Teaching}

To understand the current methods for English language teaching, the reasons for the dominance of several teaching methods in language classrooms, as well as the challenges that teachers and learners encounter, it is necessary to understand the major methods for language teaching. These methods are summarized below.

The grammar-translation method is "a way of studying a language that approaches the language first through detailed analysis of its grammar rules, followed by application of this knowledge to the task of translating sentences and texts into and out of the target language" (Richards, 2001, p. 5). According to the grammar-translation method, reading and writing are the main focus, while listening and speaking are not emphasized. Vocabulary is taught using bilingual word lists, grammar is taught deductively, and the student's native language is the medium for instruction (Richards, 2001).

The direct method proposes that a foreign language should be learned the way children learn their first language, or the way children being transferred to another country acquire a second language naturally and without great difficulty (Rivers, 1968). Foreign language learning, therefore, must be natural, and language should be taught without translation and without the use of the learner's native language. Instead, it should be taught through demonstration and action. Grammar should be taught inductively, and speaking and listening should be developed in small and intensive classes (Richards, 2001).

The audio-lingual method is a language teaching method that originated from the intensive language training courses of the US military and focuses on aural and oral skills. These courses were also known as the army method. Later, in its variations and adaptations, this method was renamed the audio-lingual method in the 1950s (Brown, 2007a). The audio-lingual method is described by Brown (2007a) as follows:

New material is presented in dialogue form, little or no grammatical explanation is used, grammar is taught inductively, structural patterns are taught using repetitive skills, vocabulary is strictly limited and learned in context, there is much use of tapes, language labs and visual aids, very little use of the mother tongue by teachers is permitted (p. 111).

Communicative language teaching aims to develop the learner's communicative competence. As pointed out by Richards (2001), in communicative language teaching classes, tasks and activities are designed to enable learners to achieve communicative objectives by participating in communicative processes such as exchanging information, negotiation of meaning, and interaction. In communicative language teaching, learner-centered learning is emphasized. Characteristics of communicative language teaching are summarized by Brown (2007a) as follows:

Classroom goals are focused on all of the components of communicative competence and not restricted to grammatical or linguistic competence, language techniques are designed to engage learners in the pragmatic, authentic, functional use of language for meaningful purposes, fluency and accuracy are seen as complementary principles underlying communicative techniques, students ultimately have to use the language, productively and receptively, in unrehearsed contexts (p. 241).

\subsection{Issues Relating to the Activity of English Teaching and Learning}

\subsubsection{The Roles of Teachers and Learners}

According to Lochana and Deb (2006), teachers have recently realized the importance of using a student-centered approach to teaching where teachers can help students to learn the target language in context and to use it in real situations both inside and outside the language classroom. Collaborative or cooperative learning is described by Richards (2001) as a student-centered approach in which learners use cooperative activities, such as pair work or group work, to: express their viewpoints and opinions; share their ideas, information and experience; and discuss and debate with each other. Jacobs and Hall (2002) point out that, when using cooperative learning activities in language classrooms, teacher talk should be reduced and students' talk should be increased, with a focus on negotiation of meaning and a greater amount of comprehensible input. In addition, a relaxed classroom atmosphere and motivation for learning should be emphasized. Collaborative learning aims to provide learners with interactive tasks that can help them develop communicative competence (Richards, 2001).

Student-centered collaborative approaches require teachers and learners to play roles that are different from the traditional approaches. According to Brown (2007b), teachers play five main roles when using collaborative activities involving pair work and group work for students in language classrooms. Teachers should help students build up enough classroom language so that they can understand the teachers' instructions, choose group techniques appropriate for students, plan group work, monitor tasks, and help debrief students to start the activity. 
Littlewood (1981) advises that, while students are involved in communicative activities such as pair work or group work, teachers should act as observers who walk around the class to give students guidance to start their discussions, give students advice when necessary, and help them to solve disagreements within pairs or groups. However, before learner-centered activities are undertaken, teachers should ensure that all students are clear about the tasks and instructions so that the students are able to start their work independently and confidently.

Besides the teachers' roles, the learners' roles in student-centered collaborative learning approaches are described by (Breen \& Candlin, 1980) as follows:

The role of learner as negotiator-between the self, the learning process, and the object of learning-emerges from and interacts with the role of joint negotiator within the group and within the classroom procedures and activities which the group undertakes. The implication for the learner is that he should contribute as much as he gains, and thereby learn in an interdependent way (p. 110).

Students' interdependence is considered important in student-centered learning approaches. Students are expected to interact with each other, rather than with teachers (Richards, 2001). To acquire this capacity, students need to have confidence, high motivation and positive attitudes toward their study (Liu \& Zhang, 2007). Therefore, learner autonomy and motivation are important factors for successful teaching and learning.

In relation to the roles of teachers and learners in Vietnam, while teachers play the role of controllers and knowledge providers, the students' role is quite passive (Le, 1999; Nhan \& Lai, 2012; Tin Tan, 2010). This is because Vietnamese people are generally still influenced by Confucianism (Le, 1999; Pham, 2006). However, some Vietnamese learners are no longer completely passive (Mai \& Iwashita, 2012; Nguyen, 2002), and instead of enjoying traditional whole-class settings, they prefer to participate in activities such as pair work and group work that help them to use the language and enable them to explore problems themselves as well as co-operate with their friends to acquire knowledge effectively (Mai \& Iwashita, 2012). In classroom communication activities, many students have the desire to express their thoughts orally, provide discussion topics and share their experiences with the class (Tomlinson \& Dat, 2004).

\subsubsection{The Use of Teaching Materials}

Teaching materials play an important role in promoting communicative language use. There are three kinds of teaching materials: text-based, task-based, and realia. These can be textbooks, games, role plays, simulations, and task-based communication activities designed to support communicative language teaching. Different kinds of authentic objects can be used in a communicative language teaching class to support communicative activities, from language-based realia such as signs, magazines, and newspapers to graphic and visual sources such as maps, pictures, symbols, graphs, and charts (Richards, 2001).

The use of teaching materials has a major impact on the activity of language teaching. Abebe and Davidson (2012) point out that students are eager to learn vocabulary with the assistance of visual materials, and that the use of visual materials enhances the students' ability and opportunity to use language to express their ideas and feelings. However, Abebe and Davidson (2012) also found that teachers rarely use visual materials such as cards, charts, and real objects in teaching, despite the majority of teachers and students admitting that visual materials help students learn language effectively. Mathew and Alidmat (2013) agree that teacher's use of audio-visual aids helps students to understand lessons more and improves their English language skills, such as pronunciation skills or conversational skills, through listening to native speakers. In addition, the use of audio-visual materials also helps to make classroom activities more interesting and helps the students to remember the lessons longer. A study conducted by Aduwa-Ogiegbaen and Iyamu (2006) found that textbooks, workbooks, dictionaries, chalkboards, and posters are dominant in English classrooms, whereas modern media such as audio and video, programmed texts, language laboratories, flashcards, computers, magazines, and newspapers are rarely used.

In brief, considerable research relating to English teaching has been conducted in a number of countries, including Vietnam. However, few of these studies have been conducted at a particular Vietnamese higher education institution. Therefore, it was necessary to conduct further research, and this study provides a snapshot of English training in Vietnamese higher education by focusing on HUTECH University (HUTECH) as a case study. The results of this study provide evidence that teachers can use to adjust their teaching activities, and university leaders can develop appropriate strategies to make English teaching and learning more effective.

\section{The Study}

The data presented in this paper were a part of a larger study of factors affecting English teaching and learning in a Vietnamese higher education. The study was conducted at HUTECH with the participation of managers, teachers, and students. Various data collection techniques were employed, including questionnaires, interviews, 
and class observations, to obtain both qualitative and quantitative data. This paper focuses on the data obtained from eight class observations that sought to answer the following question: What factors affect English teaching and learning in higher education?

\subsection{Data Collection}

Eight classes from various major disciplines were selected for non-participant observations, and each observation lasted 45 minutes. The main focus of the class observations was teachers' activities and interactions between teachers and students, rather than individual students. All observations were conducted by the researcher and arranged with the permission of the teachers and with due consideration of their convenience and time availability. Observation notes were used to record data.

\subsection{Data Analysis}

The class observations were coded in identification numbers as shown in Table 1.

Table 1. Coding for class observations

\begin{tabular}{lll}
\hline Classes observed & Identification numbers & Observation dates \\
\hline Class 1 & C1 & 15 April 2012 \\
Class 2 & C2 & 18 April 2012 \\
Class 3 & C3 2 19 April 2012 \\
Class 4 & C4 & 21 April 2012 \\
Class 5 & C5 & 23 April 2012 \\
Class 6 & C6 & 28 April 2012 \\
Class 7 & C7 & 28 April 2012 \\
Class 8 & C8 & 29 April 2012 \\
\hline
\end{tabular}

The field notes from the class observations were read through to identify the main ideas. The field notes were then read line by line to obtain the emerging themes. When the main themes were obtained, an inductive approach was used to code the data within each main theme. Similar categories were grouped together to make sub-themes, and these categories were labeled to indicate their content. The findings were then interpreted in narrative passages. Some parts of the field notes were extracted and have been quoted in this paper to support the analysis and findings. For example, the extract coded as Observation excerpt C1.15.04.2012.25 means that the excerpt was extracted from line 25 of the observation notes from Class 1 observed on 15 April 2012.

In data analysis, some procedures were taken to enhance validity and reliability of findings. Intercoder agreement was applied, which allowed the researcher to ask another person to cross-check the codes (Creswell, 2009). The coders agreed on most of the codes used. In addition, peer debriefing was also used "to enhance the accuracy of the account. This process involves locating a person (a peer debriefer) who reviews and asks questions about the qualitative study so that the account will resonate with people other than the researcher" (Creswell, 2009, p. 192).

\section{Findings}

The results from the class observations indicated that there were many problems affecting the quality of English teaching and learning at HUTECH. These problems included: the teachers' teaching styles and methods; teachers' classroom management; teachers' investment for teaching; and students' abilities and attitudes.

\subsection{Uninteresting Teaching Style}

The most common theme from the observations was that the atmosphere in the classes was not very exciting. There were not many activities designed to arouse the students' interest. During the lessons, most of the teachers did not use songs or games to teach and entertain the students, despite songs and games being believed to make classes happy and more relaxing, especially language classes. If the teachers could choose appropriate songs or games for lessons, their students would be more interested and the lessons would be more effective. Only one young female teacher used a song and a game for her class. However, the song she used was only for entertainment and did not connect well with the content of the lesson. Moreover, the game she designed only focused on developing students' vocabulary and did not contain communicative practice. The game activity in 
Class 1 was conducted as follows:

The teacher distributed the handouts of the crossword to the whole class, then asked the students to fill in the crossword. The teacher said "I will receive the handouts from the first five people who finish and submit to me, then I will check to see who will get most correct answers. That person will be the winner". Then the teacher let the students fill in the crossword individually. Some minutes later, the first five handouts were submitted to the teacher. Then, she asked the whole class to stop and look at the screen. She showed the crossword on the screen and elicit the answers from the whole class. After the crossword was filled in completely, the teacher looked at the first five handouts submitted to her and had a quick check, then she informed to the whole class the winner. The students clapped their hands for congratulations. (Observation excerpt C1.15.04.2012.55)

The game activity described above demonstrated that the teacher had made an effort to make the students less bored in the class. However, her game only helped to improve the students' vocabulary and the students' communicative ability was not a focus. It would have been better if the teacher had used the type of crossword that required the students to work in pairs and ask each other for information, definitions, or explanations to fill out the crossword.

In addition, the teachers' lecturing style was also a concern. The popular style of the teachers observed was to spend most of their time sitting at the teacher's desk, holding the microphone, looking at the book, and talking. Some teachers also moved around the classroom, but their voice, style, and activities were not exciting. Their verbal and non-verbal language was not exploited effectively. Their voice tone was the same during the lesson, and they did not raise their voice to attract the students' attention when necessary. There were not many gestures and facial expressions to engage the students and, therefore, the students were not interested. Taking the case in Class 4 as an example:

The teacher sat at the desk, asked the students to look at page number 88. The students followed his instruction. The teacher asked the whole class to do the exercises in silence. Then, after the students finished, the teacher called the students to stand up and read aloud their answers individually. The teacher sat at the desk, listened and said if the answer was right or wrong. The teacher also corrected students' pronunciation if any. When the students gave the correct answer, the teacher said "Thank you, sit down please". When the answer was wrong, the teacher called another student until he got the correct answer. (Observation excerpt C4.21.04.2012.27)

Most teachers did not use warm-up activities at the beginning of each lesson to arouse the students' interest and lead them into the lesson. Some teachers used warm-up activities, but these activities were not enough to make the students excited and eager to learn. The beginning of the lesson in Class 2 was described as follows:

The teacher came to the class. She walked to the teacher's desk, took the book and laptop from her bag. She connected the laptop and the OHP, then opened the book. She introduced the lesson: "Today we study new lesson: 'Trying you best'. Now, open your book, page 90, please." The students did as directions. At the same time, the teacher wrote the title of the new lesson on the board. She divided the board into two columns. One column was "the present perfect tense" and the other column was "the present perfect continuous tense". Then she helped the students review the two tenses by calling two students to go to the board and write down the formation of the tenses and the examples. (Observation excerpt C2.18.04.2012.07)

In the above situation, the teacher could have made the students more interested by employing better warm-up activities. For example, she could have shown the pictures of the two actions or activities that represented the two tenses, the present perfect and the present perfect continuous, and then asked questions and elicited answers from the students. Or, she could have asked the students to play a game related to the tenses and then led them step-by-step into the new lesson. The class atmosphere was not very exciting because of the teacher's style and limited ability to attract the students' attention.

\subsection{Insufficient Time for Communicative Activities}

Another common theme from the observations was that the teachers tried to use a communicative approach in their classes, but in most of the classes observed, it was not implemented effectively or properly. All the teachers conducted pair work and group work activities in their classes, but these activities were limited to answering the questions in the textbook. There were not many opportunities for the students to communicate their own ideas. In some classes, the teachers asked the students to form pairs to ask and answer questions from the reading texts. In other classes, the teachers asked the students to do exercises in groups, and the teachers then gave marks for the whole group. Most of these questions, answers, or exercises were from the textbooks, and the teachers did not set adequate communicative situations that required the students to speak to obtain information from each other or to solve the problems together. Below is an activity in Class 3: 
After explaining to the class the use of "so" and "such", the teacher asked the students to work in pairs to do the exercise in the textbook (page 89) together. The students followed the teacher's direction. They did the exercise in pairs. In most pairs, both students read the questions in silence, then one student wrote down the answers in the book. If their partner agreed, they moved to the next question. If not, they discussed again to have the common answer. The language used for discussion was almost Vietnamese. In some pairs, they could not agree with each other for the answers, and had to call the teacher for help and asked for the correct answer from the teacher. After 10 minutes, the teacher asked the whole class to stop. Then the teacher called individual students to stand up and read aloud their answers. The teacher listened, gave feedback and corrected mistakes if any. (Observation excerpt C3.19.04.2012.43)

There was not much time allocated for communicative activities. Most pair work or group work activities were limited to asking and answering questions from the textbook, and in most of the classes observed, the students did not have opportunities to speak, present ideas or have conversations in English. In several classes, the students were given some communicative situations, but the available time was limited to around 10 minutes. This may have been because the teachers were afraid of having insufficient time for other tasks and activities, and they could not give the students much time for speaking and communication practice. However, if the purpose of the university and the teacher was to develop students' communicative ability, more time was needed to be spent on communicative tasks. Here is the description of a communicative activity in Class 5:

The teacher showed the instruction of the communicative task on the screen. The task required the students to play roles as a customer and a waiter/waitress in a restaurant. The teacher asked the students to form pairs, called student A and student B. According to the teacher, student A would play role as the customer, and student B would be the waiter/waitress. The teacher gave the handouts to all pairs in class. Student A looked at handout A, and student B looked at handout B. They had to make conversations, ask each other to get information to fill in the blanks in their handouts. The students had seven minutes to do the task. After seven minutes, the teacher asked the whole class to stop. Some pairs finished, but most other pairs did not complete yet. The teacher called some pairs who finished to read aloud their conversations in front of class. (Observation excerpt C5.23.04.2012.29)

The above activity was well-designed to help to develop students' English communication, but the time available was very limited. The students were eager to take part in this activity, but seven minutes was not enough for them to complete the task. It is highly recommended that these tasks should be used often in classes, but more time should be given to each activity.

\subsection{Grammar-Driven Teaching Model}

The grammar and text driven teaching model was quite popular. In four of the eight classes observed, the teachers focused too much time on teaching grammar. During 45 minute classes, the teachers spent most of the time reviewing grammar points that the students had already studied when they were at high school. Most of the time was spent reviewing the formation and use of some grammar structures and doing written practice exercises. This situation was due to a number of reasons. It might be because the teachers thought that grammar was very important for students and that their students needed to be good at grammar before they could study broader English skills.

This might also be due to the reality that when the teachers were students at pedagogy universities, most of them were taught grammar quite well and that led to the belief that, when they became teachers, they felt more confident to teach grammar than other skills. In addition, it might be because teaching grammar required less effort, energy and time for lesson preparation than other skills. Especially when English teachers' in Vietnam were busy teaching many classes in different educational institutions to earn a living, teaching grammar was considered helpful for them when they were too tired to conduct other activities that required considerable preparation and energy. However, despite these reasons, the researcher felt that priority should not be given to teaching grammar. There should be more time for communication and less time for grammar. Moreover, if being taught, grammar should be taught in a communicative way instead of a mechanical way. For example, to save time in class, the teacher could ask the students to review grammar points and do grammatical written exercises at home. The time in class should be used for communicating, making conversations using the structures and grammar points reviewed at home.

\subsection{Unreasonable Time Management}

Through the class observations, it was realized that the teachers' skills in time management were limited. Interestingly, all the teachers in the classes observed did not specify the time for the students to perform each activity. The teachers asked the students to do tasks, or activities individually, in pairs, or in groups, but they did 
not inform the students of the time they needed to finish. Therefore, most tasks and activities lasted longer than expected, and the teachers then had to teach quickly to finish the lesson in time. This resulted in the latter part of the lesson being ineffective when not much time was left. Furthermore, too much time was allocated for grammar and too little time for communication, which suggested that the time management of the teachers was not reasonable. Below is an activity that took place in Class 7:

The teacher showed exercise 2 about phrasal verbs on the screen. The exercise required the students to complete the sentences, using provided prepositions to make appropriate phrasal verbs for the sentences. The teacher asked the students to do the exercise in silence. After that, he asked if the class finished or not. Some students said "Yes", but some said "No". He waited some more minutes until the majority of the students finished. Then he asked the whole class to stop to check for the correct answers. He looked at the student list and called the students to read aloud their sentence individually. The teacher listened and gave feedback. (Observation excerpt C7.28.04.2012.25)

In the above activity, it would have been better if the teacher had specified the time for the students before they did the exercise (for example, five minutes). By doing this, the teacher could make the students focus more, or speed up to finish the exercise on time. This would help the teacher have more time during the lesson for other tasks or activities.

\subsection{Unclear Instructions}

One other theme arising from the observations was that some teachers did not provide clear instructions for their activities in the classes. In two out of eight classes, it was shown that the teachers' instructions were not easy for students to understand. The consequence of this was that the students' misunderstood and could not complete the tasks or did the tasks in a different way. This was illustrated by an activity in Class 8:

The teacher gave the students small handouts of the listening task. There were handouts for student A and handouts for student B. In the handouts of student A, there was a question "what would you do", and in the handouts of student B, there was a statement "if you were Lucy", or "if you were Andy", or "if you were Maureen". The teacher asked the students to listen to the tape and write down suitable information. Then the teacher played the tape twice for the students to listen. After that, he gave the students two minutes to write down their answers. Then, he called two students to write the answers on the board. However, the two students stood near the board for so long but could not write down their answers. The teacher called two other students but one student could not write anything, and one student wrote again the statement "if you were Lucy" which was already mentioned in the handout. The teacher was very angry and criticized the class. Then, the teacher spent time explaining again the use of Conditional Sentences. (Observation excerpt C8.29.04.2012.23)

In the above situation, the teacher did not give clear instructions before the task. In addition, he did not include one important step: modeling the task with an example before applying it to the whole class. The teacher should have only let the students do the task on their own when he was sure that his students were all clear about the requirements of the task. Even the researcher, who is a teacher, was confused by the instructions for the task given by the teacher.

\subsection{Large Class Size}

The most common theme from the observations was that the classes were crowded. The number of the students attending each class was around 45 , but the number enrolled according to the student list was higher, generally above 50 students. This was one of the main problems affecting the quality of English teaching and learning at HUTECH. In a classroom in general, and in a language classroom in particular, a small class size is believed to enhance educational quality. In a small class, it would be easier for the teacher to manage the activities. From the observation, it is difficult to recommend how many students in an English class at HUTECH would be reasonable. As indicated by the teachers and managers, 30 would be the ideal number of students in each class at HUTECH. Nevertheless, it was also admitted that reducing class sizes depended on the HUTECH leaders' decision. According to the teachers, large class size was a common problem in Vietnamese education, not only at HUTECH.

\subsection{Teachers' Limited Ability in Classroom Organization}

The results of the observations showed that the ability of some teachers in classroom organization was limited. In two out of eight classes observed, the teachers could not control the class well. They were quite slow in forming students into pairs or groups when they wanted to conduct communicative activities. The teachers tried to include some entertainment and communication activities to make the class happy and relaxed by using games, songs, pair work, group work, but due to the big class size, and also the teachers' limited ability in classroom 
control and organization, these activities took quite some time to organize and the class environment was chaotic. Here is a description of an activity in Class 4:

The teacher said to the whole class: "Now we practice the use of Conditional Sentences". He asked the students to form groups of four or five. The students started to form groups. After about three minutes, the teacher asked if the students were ready, some students responded "Not yet, teacher". The teacher waited. At the same time, some students were still running around to find the groups they wanted to join. Some minutes later, all groups were formed, the teacher asked each group to choose famous people and make sentences about him/her/them, using the structure "If I was him/her/them, I would...". The students worked with each other in groups. The teacher sat at the desk to observe the activity. Sometimes, he walked around the groups. After that, the teacher called one person in each group to stand up and read aloud their sentences. In some groups, students stood up and made sentences quickly, but in some other groups, students hesitated and avoided standing up to report in front of classes. (Observation excerpt C4.21.04.2012.42)

In the above example, if the teacher had better classroom control and organizational skills, he could have organized the activity more quickly and effectively, and this would help to save the class time. For example, instead of waiting for the students to form groups, he could have guided them so that the groups could be formed more quickly. In addition, while the groups were working, instead of walking around the groups to observe, the teacher could spend time listening to them, giving feedback, support or correcting their mistakes in forming sentences and pronunciation. Moreover, the teacher should also ask the groups to appoint one person in each group to write down the ideas of the group, and then the teacher could call on one student in each group to stand up and report to the class. There are many ways to organize the classroom activities effectively, and depending on the situation, the teachers could choose which activities are most appropriate for their classes and their students. However, despite the activities and strategies being used, they should help to save class time and make the class well-organized and effective for students.

\subsection{Unequal Students' Levels}

The students' English ability in the classes was also observed, and the results demonstrated that there was a difference in the English ability between the classes, and between the students in the same class. It was found that students from the classes related to business studies were more energetic and interested in the lessons and studied better than the students from the classes related to technology. However, it was also found that, even in the same class, the English levels of the students were not equal. Some students could respond well and immediately to the teacher, while some other students had difficulty in finding the answers to the teacher's questions. In addition, the students' attitudes were also different. Some students were quite active and willing to raise ideas, but some other students preferred keeping quiet.

\subsection{Not Much Investment for Lesson Preparation}

Observations of the teachers' lesson preparation before classes found that there was also a problem. In most classes observed, through the teachers' performance and the activities during the class time, it was evident that the teachers did not spend much time preparing the lessons before classes. Most activities were simple and repetitive. The common classroom activities were those where the teachers looked at the course book and explained the lesson content. The students did the exercises in the course book, and then the teachers called upon the students to stand up to read the answers aloud or write the answers on the board. There were not many teaching materials other than the course book and its accompanying CD used in the classes.

The above problem was caused by a number of reasons, but perhaps the most common was that the teachers were too busy with teaching and their overall workload. In Vietnam, there is a high demand for English teachers, and English teachers are always busy with full teaching schedules. Most English teachers worked in at least two workplaces. They often worked full-time at one workplace and part-time at other workplaces, usually in evening language centers. Very few English teachers worked at only one workplace. The basic salary in one workplace is not high, compared with the increasing living costs in Vietnam, and the teachers had to seek additional work. Many English teachers in Vietnam taught two to three shifts a day: morning, afternoon, and evening. This resulted in less investment for lesson preparation before classes.

\subsection{Teachers' Limited Use of Teaching Aids and Technology}

The results of the observations also showed that teaching aids and technology were not used much by the teachers. Among the eight classes observed, in only three classes, the teachers prepared handouts for their students. However, these handouts were only used for small games or tasks. Moreover, although all classrooms were equipped with over-head projectors, not all teachers used them for their lessons. In three of the eight classes 
observed, the teachers did not use over-head projectors at all, despite over-head projectors being believed to be very helpful if the teachers could use them effectively. The teaching materials used by these teachers were mainly textbook and CD players.

In the three other classes, the teachers used over-head projectors but they did not use them effectively to facilitate high quality teaching. In these three classes, the over-head projectors were mainly used for showing enlarged images of pages from the textbook so that all students could focus, or for presenting vocabulary lists prepared in advance at home for students to copy down in their books and then read aloud.

In only two of the eight classes observed, the teachers used over-head projectors effectively. They prepared the lessons at home as PowerPoint slides, and included pictures and video clips to attract the students' attention and increase the effectiveness of the lessons. If all the teachers could use technology effectively, the quality of the teaching would increase.

\subsection{Students' Role Was Not Estimated Well}

Through the observations, it was found that some teachers gave their students opportunities to talk, discuss, express opinions, and the students were also willing to present ideas and were confident to talk in front of their classmates. However, this practice only happened in some classes and with some groups of students, but not with all classes and all students. In most classes, the students' role was not exploited effectively. It was observed that in English classes, the Vietnamese language was still used a lot by teachers and students. Most students were not shy when talking to teachers in Vietnamese, but were not confident to speak in English to each other. This illustrated that the students were not passive, but their confidence in using English was limited. In addition, the teachers' teaching method was also a factor inhibiting the students from being active. Some teachers preferred sitting at the desk and lecturing, and this habit makes students become passive in classes.

\section{Discussion}

The results from the class observations support previous studies that point out that the grammar-translation method is still the most popular method and the communicative language teaching is not focused (Gao, 2012; Le, 1999; Mondal, 2011). This indicates that the use of traditional teaching methods such as the grammar-translation method and the limited implementation of communicative approaches such as communicative language teaching are not only the issue facing English teaching in Vietnamese higher education but also in English as a foreign language countries. As described by Cook (2001), Richards (2001), and Rivers (1968), the grammar-translation method does not require much effort, preparation and imagination from teachers. With the grammar-translation method, teachers usually follow the textbooks page-by-page, exercise-by-exercise. When teachers are tired, they can set a written exercise for the whole class to do. It is also easy for the teachers to make tests and mark papers, and this can be another reason for the popular use of traditional methods in English teaching in Vietnamese higher education where English teachers are too busy with their teaching schedule and workload.

The results from the observations reinforce the previous studies that reveal the teachers' insufficient use of teaching aids and teaching materials in English classes (Abebe \& Davidson, 2012; Aduwa-Ogiegbaen \& Iyamu, 2006; Yilmaz, 2011). According to Abebe and Davidson (2012), teachers rarely use visual materials such as cards, charts, and real objects in language teaching, even when they admit the effectiveness of these visual aids to the students' learning. Aduwa-Ogiegbaen and Iyamu (2006) also point out that textbooks, workbooks, dictionaries, chalkboards, and posters are dominant in English classrooms, whereas modern materials such as audio and video, programmed texts, language laboratories, flashcards, computers, magazines, and newspapers are rarely used.

There are some reasons hindering the teachers' use of teaching aids. The first reason is that it takes the teachers' time. To have effective teaching materials for the lessons, the teachers have to spend time seeking, designing, and selecting the appropriate teaching aids. But in reality, the teachers may not have adequate time to do so. The workload associated with a lot of teaching hours may prevent the teachers from investing time in preparing visual and modern teaching materials for their classes. Another reason that may discourage the teachers' use of teaching aids is the teachers' skill in using technology and technical equipment. The study by Gao (2012) found that teachers lack confidence in the application of technology in English teaching. Although the teachers advocate the use of technology in English classes, they do not know how to apply it effectively. Therefore, to motivate teachers to use of teaching aids in classes, the teachers' workload should be reduced so that they will have more time to invest in preparing quality teaching materials for their lessons. In addition, there should be programs that train teachers in the use of technical aids, operating audio-visual equipment, and selecting appropriate audio-visual resources for classroom activities (Mathew \& Alidmat, 2013). 
The teachers' lack of preparation time also needs to be addressed. According to Harman, Hayden, and Pham (2010), the salaries for teaching staff in higher education in general in Vietnam are still low and teachers, therefore, have to take other casual or part-time jobs after hours. If so, what solution could encourage teachers to invest more time and effort for their teaching. Besides adjusting the system-related factors, such as class size, students' levels, teaching time, tests, and exams, the university leaders should also pay attention to teacher-related factors such as teacher recruitment, teacher assessment, teacher training and professional development to increase the teacher quality because "teachers play a key role in changes to teaching methodology and contribute to improvements in the quality of education, especially English as a foreign language teachers who have to meet the needs and standards of English as an international language" (Vo \& Nguyen, 2010, p. 205).

The study results raise some interesting discussions about the role of learners in English classes. Through class observations, it was found that the students themselves are not totally passive. This confirms previous studies that found that Vietnamese learners are no longer completely passive (Mai \& Iwashita, 2012; Tin Tan, 2010; Tomlinson \& Dat, 2004). Instead of traditional whole-class settings, they prefer to participate in communicative activities that enable them to use the language to express themselves, explore problems and exchange ideas with their friends to acquire knowledge effectively (Mai \& Iwashita, 2012). However, although Vietnamese students are not completely passive, and although they prefer to participate in communicative activities, some de-motivating factors have prevented them from being active in English classes. The first reason is the students' lack of confidence in their English proficiency. Other factors, such as exam-oriented teaching and crowded classes with unequal students' English levels might also hinder the application of learner-centered approaches and hinder the students' active participation in English classes. To facilitate the active role of learners in English classes, the learner-centered approach should be implemented. In this situation, the results from the study conducted by Dang (2006) might have some implications. According to Dang (2006), there are four important elements contributing to the successful implementation of learner-centered approaches: the context in which national policies and universities' policies create a supportive environment; the curriculum together with learning materials and learning activities designed with teachers' and students' contributions; the qualified and experienced teachers who were confident in performing their roles in accordance with the learner-centered approach perspectives; and the learners' awareness of their roles in the language learning process.

\section{Conclusion}

The study provides an insight of the English language teaching activity in classrooms at HUTECH, which is a part of Vietnamese higher education. The de-motivating factors of English language teaching are related to: teachers' uninteresting teaching styles and ineffective teaching methods; the lack of time; teachers' limited skills in time and classroom management; large class sizes; unequal students' English abilities; inadequate investment for lesson preparation; teachers' limited use of teaching aids and technology; and students' lack of confidence. To improve the quality of English language teaching at HUTECH in particular, and in Vietnamese higher education in general, the following recommendations are provided:

- The need to increase the time available for English teaching that will be sufficient to develop students' skills in listening, speaking, reading, and writing.

- The need to reduce the class size to about 30 students to facilitate the effective use of communicative activities in classes.

- The need to apply placement tests to group students into appropriate classes.

- The need to revise the testing and assessment content that covers the skills in listening, speaking, reading, and writing.

- The application of various teaching methods, especially the communicative approach, which will help to improve students' communicative competence.

- The need to implement effective teacher professional development programs.

- More support from the university leaders, especially financial assistance.

- The requirement for more effort and autonomy from students.

\section{References}

Abebe, T. T., \& Davidson, L. M. (2012). Assessing the role of visual teaching materials in teaching English vocabulary (Report). Language In India, 12(3), 524.

Aduwa-Ogiegbaen, S. E., \& Iyamu, E. O. S. (2006). Factors affecting quality of English language teaching and 
learning in secondary schools in Nigeria. College Student Journal, 40, 495.

Breen, M., \& Candlin, C. N. (1980). The essentials of a communicative curriculum in language teaching. Applied Linguistics, 1(2), 89-112. http://dx.doi.org/10.1093/applin/I.2.89

Brown, H. D. (2007a). Principles of language learning and teaching (5th ed.). White Plains, NY: Pearson Longman.

Brown, H. D. (2007b). Teaching by principles: An interactive approach to language pedagogy (3rd ed.). USA: Sanfrancisco State University.

Cook, V. (2001). Second language learning and language teaching (3rd ed.). London: Arnold.

Creswell, J. W. (2009). Research design: Qualitative, quantitative, and mixed methods approaches (3rd ed.). Thousand Oaks, Calif.: Sage Publications.

Dang, H. V. (2006). Learner-centeredness and EFL instruction in Vietnam: A case study. International Education Journal, 7(4), 598-610.

Gao, L. (2012). Digital Technologies and English Instruction in China's Higher Education System. Teacher Development. http://dx.doi.org/10.1080/13664530.2012.667967

Harman, G. S., Hayden, M., \& Pham, T. N. (2010). Reforming higher education in Vietnam: Challenges and priorities. Dordrecht: Springer.

Jacobs, G. M., \& Hall, S. (2002). Implementing cooperative learning. In J. C. Richards, \& A. W. Renandya (Eds.), Methodology in language teaching: An anthology of current practice (pp. 52-53). New York: Cambridge University Press.

Le, V. C. (1999). Language and Vietnamese pedagogical contexts. Paper presented at the Fourth International Conference on Language and Development, Hanoi.

Littlewood, W. (1981). Communicative Language Teaching: An Introduction. Cambridge: Cambridge University Press.

Liu, L. (2003). A New Perspective on the Goals of TEFL in China. The internet TESL Journal, IX(11).

Liu, M., \& Zhang, L. (2007). Student perceptions of native and non-native English teachers' attitudes, teaching skills assessment and performance. Asian EFL Journal, 9(4), 157-166.

Lochana, M., \& Deb, G. (2006). Task-based teaching: Learning English without tears. Asian EFL Journal, 8(3), 140-164.

Mai, N. K., \& Iwashita, N. (2012). A comparision of learners' and teachers' attitudes toward communicative language teaching at two universities in Vietnam. University of Sydney Papers in TESOL, 7, 25-49.

Mathew, N. G., \& Alidmat, A. O. H. (2013). A study on the Usefulness od Audio-Visual Aids in EFL Classrooms: Implications for Effective Instruction. International Journal of Higher Education, 2(2). http://dx.doi.org/10.5430/ijhe.v2n2p86

Mondal, N. K. (2011). Evaluation of English language teaching methods used in higher secondary education in Bangladesh (Report). Language In India, 11(12), 181.

Nguyen, T. H. A. (2002). Cutural effects on learning and teaching English in Vietnam. The Language Teacher, 26(1).

Nhan, N. T., \& Lai, H. T. (2012). The enhancement of learner autonomy and the growth of English language proficiency (Report). Language In India, 12(4), 427.

Pham, T. H. T. (2006). The Development of the Higher Education Sector of Vietnam within the Globalization Discourse: Using Futures Methodologies. Journal of Futures Studies, 11(2), 35-60.

Richards, J. C. (2001). Approaches and methods in language teaching (2nd ed.). Cambridge, U.K.

Rivers, W. M. (1968). Teaching foreign-language skills. Chicago: University of Chicago Press.

Rivers, W. M. (1978). A practical guide to the teaching of English as a second or foreign language. New York: Oxford University Press.

Tin Tan, D. (2010). Learner Autonomy in EFL Studies in Vietnam: A Discussion from Sociocultural Perspective. English Language Teaching, 3(2).

Tomlinson, B., \& Dat, B. (2004). The Contributions of Vietnamese Learners of English to ELT Methodology. 
Language Teaching Research, 8(2), 199-222. http://dx.doi.org/10.1191/1362168804lr140oa

Vo, L. T., \& Nguyen, H. T. M. (2010). Critical Friends Group for EFL Teacher Professional Development. ELT Journal, 64(2), 205-213. http://dx.doi.org/10.1093/elt/ccp025

Yilmaz, C. (2011). Teachers' perceptions of self-efficacy, English proficiency, and instructional strategies (Report). Social Behavior and Personality: An International Journal, 39(1), 91. http://dx.doi.org/10.2224/sbp.2011.39.1.91

\section{Copyrights}

Copyright for this article is retained by the author(s), with first publication rights granted to the journal.

This is an open-access article distributed under the terms and conditions of the Creative Commons Attribution license (http://creativecommons.org/licenses/by/3.0/). 